\title{
Phytoremediation of Metal (PB, NI, ZN, CD and CR) Contaminated Soils Using Canna Indica
}

\author{
V. SUBHASHINI and A. V. V. S. SWAMY \\ Department of Environmental Sciences, Acharya Nagarjuna University, \\ Nagarjuna Nagar, Guntur, 522510. Andhra Pradesh, India.
}

http://dx.doi.org/10.12944/CWE.9.3.26

(Received: August 30, 2014; Accepted: September 29, 2014)

\begin{abstract}
Heavy metal pollution has become one of the most serious environmental problems today. Remediation of heavy metal polluted soils is one of the significant topics in environmental restoration. As a plant based technology the success of phytoremediation is inherently dependent upon proper plant selection. The present study is an attempt to test the potential of the native species to remove heavy metals from the soil. A pot experiment was conducted to study the metal accumulation capacity of Canna indica L. Canna indica was known as Indian shot belongs to the family Cannaceae. High biomass herb species was selected to restrict the passage of contaminants into the food chain by selecting non-edible, disease resistant and tolerant plants and have very pleasant flowers. Based on the BCF and TF the plant species was used in $\mathrm{Pb}, \mathrm{Zn}$ and $\mathrm{Cr}$ phytoextraction process and $\mathrm{Ni}$ and $\mathrm{Cd}$ phytostabilization processes. Finally it was concluded that the species was good accumulator of $\mathrm{Pb}, \mathrm{Ni}, \mathrm{Zn}, \mathrm{Cd}$ and $\mathrm{Cr}$.
\end{abstract}

Key words: Metal, Canna Indica, Soil, $\mathrm{Pb}, \mathrm{Ni}, \mathrm{Zn}, \mathrm{Cd}, \mathrm{Cr}$.

\section{INTRODUCTION}

An extensive area of the world is contaminated with organic and inorganic pollutants including heavy metal pollutants ${ }^{1}$. Organic pollutants include solvents like trichloroethylene (TCE) ${ }^{2}$, herbicides, atrazine ${ }^{3}$. Inorganic pollutants include plant macronutrients such as nitrates and phosphates, micronutrients, $\mathrm{Cr}, \mathrm{Cu}, \mathrm{Fe}, \mathrm{Mn}, \mathrm{Mo}, \mathrm{Ni}$ and $\mathrm{Zn}$ and nonessential elements, As, Cd, Co, F, Hg, Se, $\mathrm{Pb}, \mathrm{V}$ and radionuclides, 238U, 137Cs and $90 \mathrm{Sr}^{4}$. Increasing mining activities in many countries are contributing to heavy metal (HM) pollution of water, soil and air $5,6,7,8$. Metals like Cadmium (Cd), Lead $(\mathrm{Pb})$, Zinc $(\mathrm{Zn})$ and Chromium $(\mathrm{Cr})$ when present in high concentrations in soil exert potential toxic effects on overall growth and metabolism of plants and bioaccumulation of such toxic metals in the plant poses a risk to human and animal health ${ }^{9}$.
Phytoremediation is a technology that exploits the natural ability of green plant's to remove contaminants from the environment or render toxic compounds harmless. Phytoremediation has been attracting attention as a rapidly developing, inexpensive plant-based remediation technology. Plant species vary significantly in the ability of accumulating metals from contaminated soils, as a balance between the uptake of essential metal ions to maintain growth and development and the ability to protect sensitive cellular activity and structures from excessive levels of essential and non-essential metals is required ${ }^{10}$. Popular species for phytoextraction are Indian mustard and sunflower because of their fast growth, high biomass, and high tolerance and accumulation of metals and other inorganics ${ }^{11}$. Reeves and Baker ${ }^{12}$ reported that 45 plant families are known to contain metalaccumulating species. Such plants can accumulate 
As, $\mathrm{Cu}, \mathrm{Co}, \mathrm{Cd}, \mathrm{Mn}, \mathrm{Ni}, \mathrm{Se}, \mathrm{Pb}$ or $\mathrm{Zn}$ up to levels that are 100 to 1,000 times of those normally accumulated by plants grown under the same conditions ${ }^{13}$. Recently, Sonchus asperand Corydalis pterygopetata grown on lead and zinc mining area in China have been identified as heavy metal hyper accumulators ${ }^{14}$.

Thlaspi caerulescens has been identified as a $\mathrm{Zn}$ and $\mathrm{Ni}$ hyperaccumulator ${ }^{15}, 16$. Long et al ${ }^{17}$ have recently reported a large biomass plant species, Sedum alfreddi, growing in some ancient $\mathrm{Pb}-\mathrm{Zn}$ mine areas in Eastern China, which can also hyperaccumulate $\mathrm{Zn}$. Sekabira et al., ${ }^{18}$ determined heavy metal concentrations and distribution in Commelina benghalensis (L.) and Cynodon dactylon (L.) that grows in different polluted sites along the urban stream sediments of the Nakivubo drainage ecosystem in Kampala, Uganda and reported that the bioaccumulation factor and translocation factor values (BAF and TF > 1) for both plant species were greater than one for $\mathrm{Cu}$ at some sites suggesting efficient accumulation in the shoot. BAF $>1$ and TF $<1$ values for $\mathrm{Pb}, \mathrm{Cd}$ and $\mathrm{Zn}$ suggest accumulation in roots and qualify these plants also as good candidates for Phytostabilization.

\section{MATERIALS AND METHODS}

\section{A brief description of the selected plant species Canna indica, $L$ :}

Canna indica $\mathrm{L}$. belong to the family Cannaceae. A native of the Caribbean and tropical Americas that is also widely cultivated as a garden plant. It is a perennial growing from $0.5 \mathrm{~m}$ to $2.5 \mathrm{~m}$. Canna indica var. indica L., a medium sized species, rhizomes are thick, up to $3 \mathrm{~cm}$ in diameter. Canna indica species can be used for the treatment
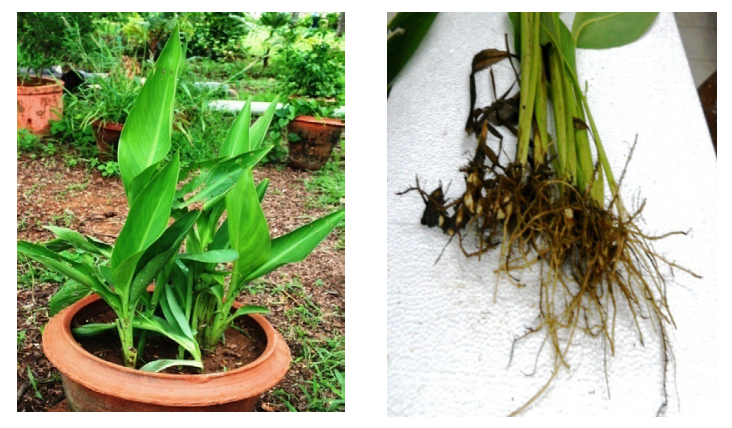

Canna indica Plant and Roots of industrial waste waters through constructed wetlands $^{19,20}$.

Canna indica seedlings were grown in pots filled with garden soil. The seedlings were collected from the uncontaminated soils. All the selected seedlings were of uniform size and free of any disease symptoms. The heavy metals selected for the study was lead, nickel, zinc, cadmium and chromium, the metal uptake was estimated in root, stem and leaves for every 20 days for a total period of 60 days. In addition a control set of experimental pots was also maintained. The heavy metal solutions of $5 \mathrm{mg} / \mathrm{L}$ was prepared from the stock and administered to the plants and care was taken to avoid leaching of water from the pots. The metal uptake was estimated once in every 20 days up to 60 days (2 months). The sample plants were removed from the pots and washed under tap water and then with distilled water. The collected plants were air dried, then placed in a dehydrator for 2-3 days and then oven dried for four hours at $100{ }^{\circ} \mathrm{c}$. The dried samples of the plant were powdered and stored in polyethylene bags. The powdered samples were subjected to acid digestion. 1gm of the powdered plant material were weighed in separate digestion flasks and digested with $\mathrm{HNO}_{3}$ and $\mathrm{HCl}$ in the ratio of $3: 1$. The digestion on hot plate at $110^{\circ} \mathrm{c}$ for $3-4$ hours or continued till a clean solution was obtained. After filtering the filtrate was analyzed for the metal contents in AAS.

\section{Bioconcentration factor (BCF) and Translocation factor (TF):}

A plant's ability to accumulate metals from soils can be estimated using the BCF, which is defined as the ratio of metal concentration in the roots to that in soil. A plant's ability to translocate metals from the roots to the shoots is measured using the TF, which is defined as the ratio of metal concentration in the shoots to the roots. Enrichment occurs when a contaminant taken up by a plant is not degraded rapidly, resulting in an accumulation in the plant. The process of phytoextraction generally requires the translocation of heavy metals to the easily harvestable plant parts, i.e. shoots. Tolerant plants tend to restrict soil-root and root-shoot transfers, and therefore have much less accumulation in their biomass, while hyperaccumulators actively take up and translocate metals into their aboveground 
biomass. Plants exhibiting TF and particularly $B C F$ values less than one are unsuitable for phytoextraction $^{21}$.

\section{RESULTS AND DISCUSSION}

Accumulation of Lead $(\mathrm{mg} / \mathrm{kg})$ in Canna indica:

The experiments on absorption of lead in Canna indica revealed that stem has accumulated highest quantity of lead $(18.37 \mathrm{mg} / \mathrm{kg})$ out of total accumulation of $34.52 \mathrm{mg} / \mathrm{kg}$. The absorption of lead was maximum within first 20 days in roots and stem. By $20^{\text {th }}$ day lead concentration in roots reached $19.51 \mathrm{mg} / \mathrm{kg}$ from $12.26 \mathrm{mg} / \mathrm{kg}$ and by $60^{\text {th }}$ day the concentration of lead reached to 20.59 $\mathrm{mg} / \mathrm{kg}$ while in the stem the concentrations of lead in stem reached from 8.57 to $22.41 \mathrm{mg} / \mathrm{kg}$ by $20^{\text {th }}$ day and increased to $26.94 \mathrm{mg} / \mathrm{kg}$ by $60^{\text {th }}$ day. The increase of concentration of lead in leaves was slow and steady throughout the experimental period, i.e, $2.27,4.79,8.37 \mathrm{mg} / \mathrm{kg}$ for $20-40-60$ days. $53.19 \%$ of lead remained in stems. Out of a total of $34.52 \mathrm{mg} /$ $\mathrm{kg}$ of lead $26.17 \mathrm{mg} / \mathrm{kg}$ was accumulated in above ground plant parts and only $8.34 \mathrm{mg} / \mathrm{kg}$ remained in roots. The trend of translocation reveals that lead was effectively translocated from roots to stem while from stem to leaves the translocation was poor and hence the total accumulation in stem was more than the leaves and roots.

\section{Accumulation of Nickel $(\mathrm{mg} / \mathrm{kg})$ in Canna indica:}

Nickel absorption in Canna indica was maximum during first 20 days of experiment and during the subsequent intervals of estimations (40 and 60 days) the increase of nickel concentration was 27.6 and $29.68 \mathrm{mg} / \mathrm{kg}$, respectively. The total nickel accumulation in roots was $147.21 \mathrm{mg} / \mathrm{kg}$. The total accumulation in stem was $8.35 \mathrm{mg} / \mathrm{kg}$ and 24.97 $\mathrm{mg} / \mathrm{kg}$ in leaves. Nickel might be utilized by plant in metabolism and highest accumulation in roots reveals that the translocation from roots to stem and leaves was poor.

\section{Accumulation of Zinc ( $\mathrm{mg} / \mathrm{kg})$ in Canna indica:} The total accumulation of zinc in Canna indica was $37.4 \mathrm{mg} / \mathrm{kg}, 24.41 \mathrm{mg} / \mathrm{kg}$ and 12.56 $\mathrm{mg} / \mathrm{kg}$ in roots stem and leaves respectively. The absorption of zinc in roots was maximum up to 20th day and the increase was marginal from 20-40 and 40-60 days. While in stem and roots the increase of concentrations continued to increase up to $60^{\text {th }}$ day from the beginning of the experiment. Zinc is said to help in physical stability of the plant and the

Table 1: Accumulation of Lead, Nickel, Zinc, Cadmium and Chromium (mg/kg) in different plant parts of Canna indica during the experimental period

\begin{tabular}{|c|c|c|c|c|c|c|}
\hline $\begin{array}{l}\text { Name of } \\
\text { the metal }\end{array}$ & Plant part & Control & $20^{\text {th }}$ day & $40^{\text {th }}$ day & $60^{\text {th }}$ day & $\begin{array}{c}\text { Total } \\
\text { accumulation }\end{array}$ \\
\hline \multirow[t]{3}{*}{ Lead } & Leaf & $0.57 \pm 0.25$ & $2.27 \pm 0.08$ & $4.79 \pm 0.09$ & $8.37 \pm 0.19$ & 7.8 \\
\hline & Stem & $8.57 \pm 0.09$ & $22.41 \pm 0.19$ & $23.66 \pm 0.13$ & $26.94 \pm 0.017$ & 18.37 \\
\hline & Root & $12.26 \pm 0.13$ & $19.51 \pm 0.18$ & $19.59 \pm 0.17$ & $20.59 \pm 0.16$ & 8.34 \\
\hline \multirow[t]{3}{*}{ Nickel } & Leaf & $11.12 \pm 0.46$ & $20.99 \pm 0.08$ & $26.03 \pm 0.09$ & $36.08 \pm 0.19$ & 24.97 \\
\hline & Stem & $7.56 \pm 0.44$ & $7.46 \pm 0.01$ & $14.91 \pm 0.13$ & $15.92 \pm 0.17$ & 8.35 \\
\hline & Root & $15.47 \pm 0.13$ & $26.33 \pm 0.18$ & $27.6 \pm 0.19$ & $29.68 \pm 0.16$ & 14.21 \\
\hline \multirow[t]{3}{*}{ Zinc } & Leaf & $36.45 \pm 0.19$ & $28.25 \pm 0.08$ & $43 \pm 0.09$ & $49.01 \pm 0.19$ & 12.56 \\
\hline & Stem & $52.61 \pm 0.09$ & $62.7 \pm 0.19$ & $72.19 \pm 0.13$ & $77.02 \pm 0.18$ & 24.41 \\
\hline & Root & $11.9 \pm 0.13$ & $48.1 \pm 0.18$ & $48.2 \pm 0.15$ & $49.3 \pm 0.16$ & 37.4 \\
\hline \multirow[t]{3}{*}{ Cadmium } & Leaf & $0.07 \pm 0.09$ & $0.56 \pm 0.08$ & $0.58 \pm 0.09$ & $2.66 \pm 0.19$ & 2.59 \\
\hline & Stem & $0.52 \pm 0.19$ & $2.02 \pm 0.19$ & $2.87 \pm 0.13$ & $6.56 \pm 0.18$ & 6.04 \\
\hline & Root & $0.95 \pm 0.13$ & $2.21 \pm 0.18$ & $4.55 \pm 0.14$ & $26.94 \pm 0.15$ & 25.99 \\
\hline \multirow[t]{3}{*}{ Chromium } & Leaf & $9.24 \pm 0.19$ & $9.85 \pm 0.08$ & $14.24 \pm 0.09$ & $14.29 \pm 0.19$ & 5.05 \\
\hline & Stem & $1.89 \pm 0.09$ & $21.94 \pm 0.19$ & $22.64 \pm 0.13$ & $23.64 \pm 0.17$ & 21.75 \\
\hline & Root & $29.43 \pm 0.13$ & $23.24 \pm 0.18$ & $29.08 \pm 0.19$ & $51.05 \pm 0.16$ & 21.61 \\
\hline
\end{tabular}


higher accumulation in roots and stem also reveal that same while zinc is used in very less quantities in the metabolism in leaves.

\section{Accumulation of Cadmium $(\mathrm{mg} / \mathrm{kg})$ in Canna indica:}

Canna indica accumulated a total of 34.62 $\mathrm{mg} / \mathrm{kg}$ of cadmium in 60 days of experimental period. Out of which $75.07 \%$ of cadmium remained in roots and only $24.93 \%$ was translocated to above ground plant parts i.e. $6.04 \mathrm{mg} / \mathrm{kg}(17.45 \%)$ and $2.59 \mathrm{mg} / \mathrm{kg}$ $(7.48 \%)$ in stem and leaves, respectively. The overall absorption during 20-40 days in leaves, stem and roots was slow and by $60^{\text {th }}$ day the concentration reached maximum in all the plant parts.

\section{Accumulation of Chromium ( $\mathrm{mg} / \mathrm{kg}$ ) in Canna indica:}

The accumulation of chromium in the stem of Canna indica was highest in the first 20 days of the experiment, subsequently from 20-40 and 40-60 the increase of concentration was low and consistent. However, the increase of concentrations of chromium did not show any increase in leaves. Only $5.05 \mathrm{mg} / \mathrm{kg}$ of chromium accumulated in leaves in 60 days period while the stem and roots showed equal accumulation.

Canna indica exhibited an irrational tendency in the absorption of metals. Among the three plant parts, leaves accumulated nickel in highest concentration, stem accumulated lead and chromium, while roots accumulated cadmium and zinc in highest quantities. The total accumulation was highest for zinc $(74.35 \mathrm{mg} / \mathrm{kg})$ followed by chromium (48.41 mg/kg), cadmium (34.62 mg/kg), lead $(34.52 \mathrm{mg} / \mathrm{kg})$ and nickel $(27.48 \mathrm{mg} / \mathrm{kg})$ in that order. The zinc concentrations in general are substantially higher in other plants where as in this case there was only normal hike was witnessed. The difference of accumulation among leaves, stem and roots was highest for zinc and lowest for lead. For all metals except cadmium and nickel, the absorption during first 20 days was highest and after that there was a consistent increase. The total accumulation of cadmium was higher when compared with other plants. Bio concentration factor and Translocation factor are also calculated. Lead BCF was 3.64 and TF was 3.14. Nickel BCF was3.26 and TF was 0.93 . Zinc BCF was 5.68 and TF was 0.99. Cadmium BCF was 94.61 and TF was 0.33. Chromium BCF was 3.56 and TF was 1.24. Based on the BCF and TF the plant species was used in $\mathrm{Pb}, \mathrm{Ni}, \mathrm{Zn}$ and $\mathrm{Cr}$ phytoextraction process and $\mathrm{Cd}$ phytostabilization processes. Finally it was concluded that the species was good accumulator of $\mathrm{Pb}, \mathrm{Ni}, \mathrm{Zn}, \mathrm{Cd}$ and $\mathrm{Cr}$.

\section{CONCLUSION}

Phytoremediation technology is cost effective and ecologically friendly in which plant utilizes its natural abilities to restore environment. As a plant based technology, the success of phytoremediation is inherently dependent upon proper plant selection. The plants used for phytoremediation must be fast growing and have the ability to accumulate large quantities of metal contaminants in their shoot tissue. Finally the results concluded that Canna indica was accumulator of these five metals.

\section{REFERENCES}

1. Ensley, B. D. Phytoremediation for toxic metals - using plants to clean-up the environment. In: I. Raskin and B. D. Ensley (Eds.), Rational for use of phytoremediation. John Wiley \& Sons, Inc: 3-13, (2000).

2. Newman, L. A., S. E. Strand, N. Choe, J. Duffy, G. Ekuan, M. Ruszaj, B. B. Shurtleff, J. Wilmoth, P. Heliman, and M. P. Gordon. Uptake and biotransformation of trichloethylene by hybrid poplars. Environmental Science and Technology. 31: 1062-1067, (1997).
3. Burken, J. G. and J. L. Schnoor. Uptake and metabolism of atrazine by poplar trees. Environ. Sci. Technol. 31: 1399-406, (1997).

4. Dushenkov, S. Trends in phytoremediation of Radionucleides. Plant Soil. 249: 167-75, (2003).

5. Davies B.E. Heavy metal contamination from base metal mining and smelting: implications for man and his environment. In: Applied environmental geochemistry (ed. 
I. Thornton), pp 425-462, (1983). Academic press, London.

6. LeDuc, D.L and Terry, N. Phytoremediation of toxic trace elements in soil and water. Journal of industrial microbiology \& biotechnology, 32, pp 514-520, (2005).

7. Ahmet S. and Merve S. The phytoremediation potential for strontium of indigenous plants growing in a mining area, Environmental and experimental botany, 67, 139-144, (2009).

8. Massa N., Andreucci F., Poli M., Aceto M., Barbato R., and Berta G. Screening for heavy metal accumulator among autochthonous plants in polluted site in Italy, Ecotoxicology and environmental safety, 73: 1988-1997, (2010).

9. Agrawal, V. and K. Sharma. Phytotoxic effects of $\mathrm{Cu}, \mathrm{Zn}, \mathrm{Cd}$ and $\mathrm{Pb}$ on in vitro regeneration and concomitant protein changes in Holarrhena antidysentrica. Biol. Plant. 50: 307-310, (2006).

10. Carbisu, C. and I. Alkorta. Phytoextraction: a cost-effective plant-based technology for the removal of metals from the environment. Bioresource Technol. 77: 229-236, (2001).

11. Blaylock, M.J. and J.W. Huang. Phytoextraction of metals. In: Phytoremediation of toxic metals using plants to clean up the environment (eds: I. Raskin and B.D. Ensley). Wiley, New York. 53-70, (2000).

12. Reeves, R. D. and A. J. M. Baker. Metal accumulating plants. In Raskin et al. (eds) Phytoremediation of Toxic Metals. John Wiley New York USA. 193-229, (2000).

13. Baker A. J. M., S. P. McGrath, R. D. Reeves. and J. A. C. Smith. Metal hyperaccumulator plants: a review of the ecology and physiology of a biological resource for phytoremediation of metal-polluted soils. In: Terry N. and Banuelos G. S (eds). Phytoremediation of Contaminated Soil and Water, Florida: Lewis
Publishers. 85-107, (2000).

14. Yanqun, Z., L. Yuan, C. Jianjun, C. Haiyan, Q. $\mathrm{Li}$, and C. Schvartz. Hyperaccumulation of $\mathrm{Pb}$, $\mathrm{Zn}$ and $\mathrm{Cd}$ in herbaceous grown on lead-zinc mining area in Yunnan, China. Environ. Int. 31(5): 755-762, (2005).

15. Rascio, W. Metal accumulation by some plants growing on zinc mine deposits. Oikos 29: 250 253, (1977).

16. Reeves, R. D. and R. R. Brooks. Hyperaccumulation of lead and zinc by two metallophytes from a mining area in central Europe. Environ Pollut. 31: 277-285, (1983).

17. Long, X.X., Yang, X.E., Ye, Z.Q., Ni, W.Z., and W.Y. Shi. Differences of uptake and accumulation of zinc in four species of Sedum. Acta Botanica Sinica, 44: 152-157, (2002).

18. Sekabira, K., Oryem Origa, H., Basamba, T.A., Mutumba, G. and Kakudidi, E. Application of algae in biomonitoring andphytoextraction of heavy metalscontamination in urban stream water. Int. J.Environ. Sci. Tech. 8: 115-128, (2011).

19. Choudhary. Performance of constructed wetland for the treatment of pulp and paper mill wastewater, Proceedings of World Environmental and Water Resources Congress. Bearing Knowledge for Sustainability, Palm Springs, California, USA. 4856-4865, (2011).

20. Gamble, J. S. Flora of the presidency of Madras. Bishen Singh Mahendra Pal Singh Publishers. 23-A, New Cannaught Place, Dehra Dun - 248001 (India). III. 1496, (2008).

21. Fitz, W. J. and W. W. Wenzel. Arsenic transformations in the soil-rhizosphere-plant system fundamentals and potential application to phytoremediation. J. Biotechnology. 99: 259-278, (2002). 